\title{
$\stackrel{\alpha}{\sim}$ NTERNATIONAL REVIEW Of SOCIAL RESEARCH
}

\section{Before Massification: Access to University Education in Ukraine in 1950s-1980s}

\author{
Sergiy KURBATOV \\ Institute of Higher Education, National Academy of Pedagogical Sciences of Ukraine \\ Centre for Russian and Eurasian Studies, University of Uppsala, Sweden
}

\begin{abstract}
My paper sets to analyze the Soviet policy on access to higher education during the last four decades of existence of the USSR, with a particular focus on the Ukrainian case. It includes the analysis of discourses on planned economy and central regulations regarding access to universities, and a discussion on official and unofficial benefits (Russian original 'blat') during the admission process. The findings led to the conclusion that the number of students, which increased four point four times between 1950 and 1990, was less significant per 100,000 people; thus, generally speaking, access to university education continued to be rather restrictive in social terms. This was one of the main causes of the slow development of Soviet Ukraine in scientific and technological areas.
\end{abstract}

Keywords: students, university, access to education, benefits, planned economy.

\section{Historical and social background of the higher education system in Soviet Ukraine}

The policy of the USSR in the area of education in general and higher education in particular usually meets positive evaluation. During the Soviet period, illiteracy among the population was almost entirely eradicated, and the number of people with higher education increased dramatically. 'The Soviets are prouder of their advances in education than of almost any other achievement since the Bolshevik Revolution' (Jacoby, 1971:37). In 1915, the Russian Empire with its 160 million population had 105 higher education institutions with a total number of enrolled students of 127,400 . By the end of the first five year plan (1931-1932), the Soviet Union had more than 700 higher education institutions with 406,000 students enrolled. The most significant trend in the rising number of higher educational institutions and students could be identified during the 1930s 
Table 1. The Education Level of across Different Age Groups of Ukrainian Population

\begin{tabular}{|c|c|c|c|c|c|}
\hline $\begin{array}{c}\text { Years } \\
\text { of birth }\end{array}$ & $\begin{array}{c}\text { Incomplete } \\
\text { secondary }\end{array}$ & $\begin{array}{c}\text { Complete } \\
\text { secondary }\end{array}$ & $\begin{array}{c}\text { Special } \\
\text { Secondary }\end{array}$ & Higher & N \\
\hline $1930-1980$ & $20.7 \%$ & $39.6 \%$ & $21.3 \%$ & $18.4 \%$ & 7205 \\
\hline $1930-1949$ & $35.4 \%$ & $31.2 \%$ & $18.1 \%$ & $15.3 \%$ & 2384 \\
\hline $1950-1972$ & $11.7 \%$ & $45.2 \%$ & $23.9 \%$ & $19.2 \%$ & 3602 \\
\hline $1973-1980$ & $18.5 \%$ & $39.5 \%$ & $20.0 \%$ & $22.0 \%$ & 1219 \\
\hline
\end{tabular}

Source: Oksamytna, 2006.

- in 1940-1941 there were 817 higher educational institutions with 811,700 students enrolled. A year before the collapse of the Soviet Union (19891990) there were 900 higher education institutions with 5,147,000 students enrolled in 350 cities (Savelyev et al., 1990). The dynamic changes of the relations between the number of persons with different education level across various groups of persons who were born between 1930 and 1980, are reflected in the survey 'Employment of Ukrainian Population', conducted by Kyiv International Institute of Sociology in 2003-2004 (Oksamytna, 2006). The results of this research are presented in table one:

At the end of the $19^{\text {th }}$ century, on the territory of contemporary Ukraine, there were universities in Kharkiv, Kyiv, Odessa, Lviv and Chernivtsy. A few vocational higher educational institutions were also established during this period - among them The Nizhyn Historical and Philological Institute, a Veterinary Institute and a Technological Institute in Kharkiv, a Polytechnic Institute in Kyiv and the Higher Mining School in Katerynoslav (currently Dnipropetrovsk). In 1914 there were 27 higher education institutions with approximately 25,000 students on the territory of contemporary Ukraine (Kremen and Nikolajenko , 2006). Most of them were located on the territory of the Russian Empire.

The Soviet system of higher education inherited some of the essential features of its predecessor, the academic system of the Russian Empire. Weak university selfgovernance was compensated for by strong state control. In Coleman's words, 'The Soviet Union has built up a single monolithic educational system under omnipresent party control with heavy inputs of political indoctrination at all levels.' (Coleman, 1965). Despite the lack of autonomy, universities had a state approved model of selfgovernance, in which rectors were elected by faculty and staff to serve a certain term' (Osipian, 2008:15).

We could mention that the Russian and, later, the Soviet model of a university followed the French university model, which was established in 1804 during the rule of Napoleon I and, to some extent, ignored the German university model, established by Wilhelm von Humboldt, with academic freedom as a key value of the university system, which was adopted by the elite segment of American higher education.

Therefore, since the establishment 
of the Soviet Union on December, 29, 1922 and up to its collapse in 1991, Soviet Ukraine was part of the USSR. Among other substantial points, it shared the general trend directed at the increase of the number of higher education institutions and students enrolled up to the beginning of World War II on the Ukrainian territory in 1941. By the end of 1928, in Soviet Ukraine there were 38 higher education institutions with 33,406 students enrolled (Kremen and Nikolajenko, 2006). It is worth mentioning that in the 1920s Ukrainian authorities set the course for the ukrainization of university education. As a result, in 1929, the language of teaching in the case of academic disciplines was Ukrainian, and more than 56 per cent of the students were Ukrainians (Dzuba and Shan, 2003). But this policy of cultural revival was rejected in the 1930s. In the 1940-1941 academic year, 196,800 students studied in 173 higher educational institutions of Soviet Ukraine (Savelyev et al., 1990).

During the period following World War II, in Soviet Ukraine there were 160 higher education institutions with 202,000 students in the 1950-1951 academic year. In the 1990-1991 academic year, 881 thousand students studied in 149 higher education institutions. Consequently, there is a four point four times growth in the number of students body in the context of a decreasing number of higher education institutions (Oksamytna, 2011). During four decades, from 19401941 until 1980-1981 we can notice the growth of the number of students in Ukraine per 10,000 persons: 19401941 year - 47; 1960-1961 year - 97; 1970-1971 year - 170; 1980-1981 year
-176. But in the 1980s this tendency stopped, and in the 1985-1986 year we had 167 students per 10,000 inhabitant, while in the 1987-1988 year there were only166 (Savelyev et al., 1990).

How typical was the policy of central planning, which was realized in the particular Ukrainian case? While searching for an answer to this question, we need to mention the heterogeneous character of the territory of the country, including Western Ukraine, which joined Soviet Ukraine in 1939 according to the decision of the third extraordinary session of the Supreme Soviet of Ukraine on November 14, 1939, North Bukovina, which joined Soviet Ukraine on June, 28, 1940, and Crimea, which became part of Ukraine in 1954 according to the decision of the Supreme Soviet of Russian Federation of February 5, 1954. In 1950 there were 24 higher education institutions in Western Ukraine with more than 33,000 students. There was a tendency to use Russian as the main language of instruction in this region (Myronchuk and Igoshkin, 2002). Also, the oldest university on the territory of contemporary Ukraine, Lviv University, was located in this region. It was founded in 1661, when Polish king John II Kasimir officially granted the Jesuit Collegium the title 'University'. In 1784 it was reestablished as a secular university by Austrian Emperor Joseph II (Bunina, 2013). Another important academic institution, Chernivtsi University, which was founded in 1875, was located in North Bukovina. Crimea joined Ukraine with former Tavrida University, which was founded in 1918 and reorganized into Crimea State Pedagogical Institute in 1925. Also, 
in Carpathian Ruthenia, Uzhhorod University was founded on July 19, 1945 (Masal's'kyy and Dymydenko, 2010).

Before these events, in 1938, in Soviet Ukraine there were four state Universities: 1) the University of Kharkiv, which was founded in 1805 and, in the period 1936-1999, was named after the Russian writer Maxim Gorky in; 2) Taras Shevchenko University, which was established in 1834 and had the name of the great Ukrainian poet since 1939; 3) the University of Odessa, which was founded in 1865 and, since 1945, it has borne the name of the famous biologist, Nobel Prize winner in 1908, Elie Metchnikov; and 4) the University of Dnipropetrovsk, which was founded in 1918. So, universities in Ukraine covered only a small segment of the system of higher education institutions. Guy Neave explained this phenomenon of Soviet education in the following way:

The incorporation of the highereducation system as a subset of a command economy brought a number of consequences in its wake and more particularly those related to the role and status of the university sensu stricto. In the first place, the university, either in terms of student enrollments or of numbers of establishments, constituted a minority form of higher education. Thus, in the Soviet Union of 1960, of 739 institutions of higher education covering all sectors of the economy, 40 were universities. Similarly, total student enrolments across all sectors of higher education in that same year were 2,396,000 of which slightly over 10 percent - 249,000 - were university students. Clearly, as the 'leading sector' within the Soviet model, the university discharged a very specific mission alongside the other highly differentiated sectors of higher education. This was to train researchers, to supply highly qualified academic staff to the university world and to provide teachers for secondary education (Neave, 2011:36-37).

\section{Planned Economy and Access to Higher Education in Soviet Ukraine in the 1950s-1980s}

Higher education in Soviet Ukraine was incorporated in the centralized economic and political systems, and was subject to the total control of central state authorities. When Guy Neave analyzed the expansion of the Soviet university model in Eastern Europe after 1945, he identified two basic goals of the process, which had already been achieved in the Ukrainian higher education system after World War II:

These goals were first the incorporation of universities into the apparatus of state as part of the nation's intellectual productive process; second, subordination of the higher-education system in total to the imperative demands of the economy, both in quantitative and qualitative terms, the close control exercised by central administration over capacity planning and curricular content justified on grounds as much ideological as technical (Neave, 2011:36).

The situation of access to higher education in Soviet Ukraine is a good 
illustration of the double standard policy and of the huge gap between official rhetoric and actual everyday life practice. Formally, everything in this area was perfect, and the official mass media praised the 'wise politics' of the Communist Party. In the 1961 book 'Higher Education in the USSR', the leaders of Soviet education claimed:

'Our education system has no dead end schools, all the links of the educational chain are interconnected, and the pupils pass them consecutively. Graduation from any form of secondary education establishment gives the right to enter a university or college' (Prokofiev et al., 1961:13).

The situation remained unchanged almost thirty years later, when new official representatives of the Soviet higher education system also mentioned the transparency and justice of the system of admission to Soviet universities and other higher education institutions:

All citizens of the Soviet Union who have completed secondary education have the right to apply for admission to higher education institutions. Applicants are admitted competitively to institutes and universities on the basis of their performance on entrance examinations. In order to ensure a common approach, rules of admission, applicable throughout the Soviet Union, are published annually. These determine the procedures for entrance examinations, the term of admission in connection with certain specialities and form of education (full-time, evening, or extra-mural), privileges for certain categories of applicants, special requirements in the cases of a number of specialities (medical studies, for instance), and the necessary forms to be filled (Savelyev et al., 1990:35-36).

But Susan Jacoby, who visited the USSR and conducted there research in the area of higher education, claimed quite the opposite:

Higher education in the Soviet Union is a coveted privilege granted to a relatively small minority of the nation's youth. The restricted role of the Soviet universities as leadership entry points stand in stark contrast to America's dramatic post-war surge towards quasi-universal higher education...All of the young men and women I met were far more serious and seemed to place a much higher value on their education than American students - either my college generation of the early sixties or the more radical students I subsequently wrote about as a newspaper reporter during the era of campus revolts (Jacoby, 1971:33).

The truth may be somewhere in the middle. The Soviet higher education system in Ukraine was neither as fair, nor as transparent as its official 'protectors' claimed. At the same time, principles of meritocracy (Young, 1994) were also applied. For example, in the late 1980s, when I graduated secondary school, we already knew who, from among our peers, would be admitted to the university on their own merits, and who - for other reasons, which were completely different from the principles of meritocracy. This situation coincides with the results of the research conducted by Mikk Titma, Nancy Brandon and Kadi Roosma 
in 1991, just before the collapse of the Soviet Union, in Estonia, Latvia, Belarus, Russia's Sverdlovsk region and Ukraine's Kharkiv region:

Intergenerational mobility in the finalyears of the USSR was relatively high and inheritance relatively low, as we expected. The key factors affecting a person's social destination in these industrialized and urbanized European parts of the USSR were first education and then gender... Although education was an important factor in intergenerational mobility in Soviet society, this is not necessarily evidence that Soviet society was meritocratic (Titma et al., 2003:295).

In the above-mentioned period, the key role in the management of higher education in Soviet Ukraine was played by the Ministry of Higher Education of the Ukrainian Soviet Socialist Republic (UkrSSR), founded at the beginning of 1955. The ministry controlled the teaching, methodological and scientific activities of 58 higher education institutions out of 134, which were located in Ukraine (Serhiychuk, 2002). In July 1959, it was reorganized as the Ministry of Higher and Special Secondary Education of the UkrSSR, and operated as a central-republican institution of state management, which exerted control over teaching, upbringing, scientific and research activities of higher and special secondary education institutions.

The main plans for the training and distribution of graduates of higher education institutions were under the control of the Central Committee of the Communist Party of the USSR and the officials in Moscow. For example, the Resolution of the Central Committee of the Communist Party of the USSR dated April 17, 1959, 'On Fostering the Relations between School and Life and Further Development within the System of People Education in the USSR', claimed that a great reform of higher and secondary education systems was initiated. The reform included the expansion of the network of higher education institutions, and distance and evening forms of education; the increase in the number of hours for practical training; a higher number of graduates with degrees in new technologies and other activities. The need to increase the number of graduates and to improve the material equipment of higher education institutions were the main goals of the Resolution of the Central Committee of the Communist Party of the USSR dated May 9, 1963 'On Activities for the Further Development of Higher and Special Secondary Education, through the Improvement of the Training System and Specialists' Support' (Onischuk, 2013). The results of these steps can be noted in Table two, which indicates the high percentage of the young who enrolled for higher education studies after graduation from secondary school. Subsequently, this percentage decreased dramatically (Oksamytna, 2011).

During the 1950s, there was an attempt to expand the network of higher education institutions beyond the traditional major cities. For example, the Institute of Water Management was moved from Kyiv to Rivne, while and the Institute of Soviet Trade - from Kharkiv to Donetsk. But the main segment of 
Table 2. Distribution of secondary education graduates in 1965-1980

\begin{tabular}{|c|c|c|c|c|}
\hline $\begin{array}{c}\text { Type of } \\
\text { institution }\end{array}$ & $\mathbf{1 9 6 5}$ & $\mathbf{1 9 7 0}$ & $\mathbf{1 9 7 5}$ & $\mathbf{1 9 8 0}$ \\
\hline Higher & $41 \%$ & $15 \%$ & $16 \%$ & $16 \%$ \\
\hline Secondary special & $42 \%$ & $13 \%$ & $16 \%$ & $16 \%$ \\
\hline Vocational & - & $8 \%$ & $13 \%$ & $27 \%$ \\
\hline Working place & $16 \%$ & $64 \%$ & $55 \%$ & $41 \%$ \\
\hline
\end{tabular}

Source: Oksamytna, 2011.

higher education in Soviet Ukraine was to be found in four cities: Kyiv, Kharkiv, Odessa and Lviv. In 1954, these cities hosted 70 out of 144 higher education institutions, comprising 59 percent of the total number of students (Serhiychuk, 2002). After the 1960s, the Government expanded the network of universities. According to a decision of the Council of Ministers of the USSR dated May 28, 1965, the Donetsk Pedagogical Institute, which was founded in 1937, was turned into a standard university. On February 13, 1972, the Crimea State Pedagogical Institute was turned into Simferopol State University under decision of the same authority. On August 16, 1985, the Council of Ministers of the USSR decided to reorganize the Zaporizhzhya State Pedagogical Institute into Zaporizhzhya University. Therefore, before the collapse of the USSR, there were ten universities in Soviet Ukraine located in Kyiv, Kharkiv, Lviv, Chernivtsy, Odessa, Dnipropetrovsk, Uzhhorod, Donetsk, Simferopol and Zaporizhzhya (Masal's'kyy and Dymydenko, 2010).

One of the main criteria which dictated the distribution of higher education institutions around the country was the identification of the industrial profile of a given area. For example, in the economic region of Donetsk-Predniprivya there was a network of higher education institutions, preparing future specialists for the mining industry. The network comprised the Donetsk Polytechnic Institute, the Dnipropetrovsk Mining Institute, the Komunarsk Mining and Metallurgical Institute, the Kryvyi Rih Mining Institute and Kharkiv Institute of Mining Machine Building, Automatics and Computer Science (Onischuk, 2013).

The major problem of the Ukrainian higher education system was the professional training of the faculty, most of whom did not even own an academic degree. In 1953-1954, out of 15,347 faculty members only 783 held the degree of doctor of science, while 5,010 were $\mathrm{PhD}$ candidates in science. One solution to this problem was to encourage the staff of the Ukrainian Academy of Science to teach at higher education institutions on a part-time basis. In 1954, 128 researchers from the Ukrainian Academy of Science worked for different higher education institutions on a part-time basis. The situation in the area improved as a result. In 1958, only 25 per cent or 13,548 faculty members had the academic degree of $\mathrm{PhD}$ candidate or doctor of science (Serhiychuk, 
Table 3. Research and teaching staff with and without an academic degree in 1959-1985

\begin{tabular}{|c|c|c|c|c|c|c|}
\hline Year & Total & $\begin{array}{c}\text { \% increase in } \\
\mathbf{1 9 5 9}\end{array}$ & $\begin{array}{c}\text { Total with } \\
\text { degree }\end{array}$ & $\begin{array}{c}\text { \% increase } \\
\text { in 1959 }\end{array}$ & $\begin{array}{c}\text { Doctors of } \\
\text { science }\end{array}$ & $\begin{array}{c}\text { PhD } \\
\text { candidates in } \\
\text { science }\end{array}$ \\
\hline 1959 & 23280 & 100 & 9122 & 100 & 827 & 8295 \\
\hline 1965 & 39229 & 169 & 12488 & 137 & 1108 & 11380 \\
\hline 1970 & 54292 & 233 & 19569 & 215 & 1754 & 17815 \\
\hline 1975 & 70074 & 301 & 26502 & 291 & 2330 & 24172 \\
\hline 1980 & 84836 & 364 & 32914 & 361 & 2658 & 30256 \\
\hline 1985 & 73037 & 314 & 34151 & 374 & 3034 & 31117 \\
\hline
\end{tabular}

Source: Kremen and Nikolajenko, 2006

Table 4. Ukrainian postgraduates between 1959 and 1967

\begin{tabular}{|c|c|c|}
\hline Year & Number of students & Number of graduates \\
\hline 1959 & 2346 & 427 \\
\hline 1960 & 3058 & 447 \\
\hline 1961 & 3919 & 554 \\
\hline 1962 & 4957 & 728 \\
\hline 1963 & 6037 & 511 \\
\hline 1964 & 7048 & 1282 \\
\hline 1965 & 7584 & 1638 \\
\hline 1966 & 7955 & 1898 \\
\hline 1967 & 8305 & 2107 \\
\hline
\end{tabular}

Source: Kremen and Nikolajenko, 2006

2002). The dynamics of the growing number of faculty members and of faculty with an academic degree in the higher education institutions of Soviet Ukraine is presented in Table three (Kremen and Nikolajenko, 2006).

As shown in Table three, the situation with academic degree holders among faculty during the period 19591985 improved: in 1985, out of 73,037 faculty members, 37,185 or about 51 percent held academic degrees. The introduction of postgraduate studies was the most important cause of this improvement. The dynamics of the growing number of graduates and postgraduates in 1959-1967 is presented in Table 4 (Kremen and Nikolajenko, 2006):

\section{The Admission Process: Official and Unofficial Benefits}

As mentioned before, access to higher education in Soviet times was something prestigious and desirable. Candidates faced tough competition before enrolling at a higher education institution. In Soviet Ukraine, the toughest competition was for admission to Kyiv State University, 
the Kyiv Polytechnic Institute and Lviv State University (Serhiychuk, 2002). In 1971, Susan Jacoby made the following analysis of the process of admission to university:

Every August millions of young people throughout the Soviet Union take written examinations for entrance to the university departments where they have already applied. The common American practice of applying to several universities with different admissions standards is prohibited: if a student fails to make the grade on the $M G U$ entrance exam, he cannot fall back on his application to a less prestigious university. Young men and women are kept in the dark about their fate until they receive official notices of whether they have been admitted, usually two or three weeks before the university opens. Many secondary school graduates who had counted on continuing their education find themselves unexpectedly in a factory or office as a result of a low score on the entrance exam. The exam scores generally play the most important role in determining university admission. A student's high school record, both academic and extracurricular, has some influence. It is particularly helpful to have been active in the Komsomol (Jacoby, 1971:36).

The official representatives of the Soviet higher education system described the admission process in 1990 in a much more attractive way:

In compliance with these Rules of Admission, an admission commission has been set up in each higher education institution. These commissions grant admission to the most capable and well trained applicants on the basis of an interview and the results of entrance examinations. The admission commissions, 50 per cent of the members of which must be renewed each year, are made up of senior teaching staff members of the given institutions. They are in-house units which recruit members from other institutions. Membership must be approved under an order issued by the rector of the higher education institution in question. An admission commission is usually headed by a head of department or an assistant professor. His duties include the appointment of experienced examiners, the organization of tutorials for applicants prior to the entrance examinations, and the setup of examination procedures and common assessment criteria (Savelyev et al., 1990:36-37).

As can be noticed, the admission process was regulated by centrally adopted rules. For example, in 1956 new rules of admission to higher education institutions were announced. According to such regulations, candidates with practical work experience or those who were demobilized from the Soviet army had an advantage over other applicants during the admission process. Because of high competition (in 1958, three persons on average applied for the same place at polytechnic institutes), these aspects acquired paramount 
importance. As a result, in 1961, from among those who applied for admission to higher education institutions, 73.4 per cent already had two years or more of work experience. After 1960, candidates with special recommendations from factories or collective farms, and who would return to work there after graduation, also benefited from certain advantages on admission. For example, in 1960, 360 such persons were admitted at the Kyiv Polytechnic Institute (Onischuk, 2013).

Since 1958, in order to support workers from industry and agriculture to improve their knowledge for entrance examinations, special preparatory courses were organized. They were held not only at higher education institutions, but also in industrial enterprises and collective farms. They usually lasted eight or 10 months. During the 1958-1959 academic year, more than 22,000 persons attended these courses, while in 1963-1964, more than 38,000 (Serhiychuk, 2002). Although Soviet authorities formally tried to support workers from industry and agriculture during the admission process, in truth, the parents' social background played a more important role. As specified in the survey 'Employment of Ukrainian Population', the children who were born in the period 1930-1980 had the tendency to replicate the educational status of their parents (Oksamytna, 2006). The results of this survey are presented in Table 5.

Along with the official benefits for the representatives of the working class and peasantry, there were numerous unofficial practices of supporting somebody during the admission process. As Susan Jacoby mentioned:

The disparity between the limited number of university places and the growing number of students who want to go to college leads some families to take desperate measures. Many urban parents pay hundreds or even thousands of rubles for private tutoring, hoping their children will score higher on the university entrance examination. Some instructors who had access to the examination questions have gone to jail for their part in tutoring rackets. The more honest tutors simply try to 'teach the test' in a fashion hallowed around the world. Some college admission officers have been

Table 5. Children's (1930-1980) education level as correlated with their parents'educational background

\begin{tabular}{|c|c|c|c|c|c|}
\hline $\begin{array}{c}\text { Social group of } \\
\text { parents }\end{array}$ & $\begin{array}{c}\text { Incomplete } \\
\text { secondary } \\
\text { education }\end{array}$ & $\begin{array}{c}\text { Complete } \\
\text { secondary } \\
\text { education }\end{array}$ & $\begin{array}{c}\text { Special } \\
\text { secondary } \\
\text { education }\end{array}$ & $\begin{array}{c}\text { Higher } \\
\text { education }\end{array}$ & $\mathbf{N}$ \\
\hline $\begin{array}{c}\text { Civil servant with } \\
\text { higher education } \\
\text { degree }\end{array}$ & $5.5 \%$ & $18.4 \%$ & $23.1 \%$ & $53.0 \%$ & 528 \\
\hline Worker & $17.6 \%$ & $42.4 \%$ & $25.7 \%$ & $14.3 \%$ & 2191 \\
\hline $\begin{array}{c}\text { Agricultural } \\
\text { worker }\end{array}$ & $26.5 \%$ & $45.9 \%$ & $19.0 \%$ & $8.6 \%$ & 1318 \\
\hline
\end{tabular}


involved in outright bribery - an abuse of the system that receives an unusual amount of publicity in the official press (Jacoby, 1971:37).

I remember that in the 1980 s there were two practices of tutoring for the entrance examination: 1) tutoring 'with guarantee' of admission, and 2) tutoring 'without guarantee'. The former type of tutoring was provided by the faculty of higher education institutions, who could influence the admission process, and was much more expensive. The latter was usually provided by secondary school teachers and was some form of additional training without the 'flavor of corruption'. Persons who worked at higher education institutions and who were connected in some way to the candidate's family (relatives, friends, neighbors, etc.) played an important role during the admission process. This type of favor was called blat, and represented a widespread and popular phenomenon in Soviet Ukraine. Alena Ledeneva explains the social mechanism of the blat as follows:

The constraints of socialism drove people to outwit the centralized distribution system. At the same time, the harshness of these constraints made it impossible for the regime to fully enforce the existing regulations, which created opportunities for brokers to circumvent them. 'Pushers' of constraints created value for themselves and their networks at the expense of less opportunistic players (Ledeneva, 2014:15).

\section{Conclusions}

The higher education policy which also referred to the admission process was centrally controlled in Soviet Ukraine during the 1950s-1980s. Higher education was prestigious and desirable for the majority of population, and was cultivated by mass media and officials as an intrinsic value. There was a tendency to increase the number of students, especially in the 1950s-1960s. In the 1970s-1980s, a visible stagnation occurred, possibly representing a general economic and social crisis in USSR as a part of the Soviet Union.

Although formally open and transparent, in reality access to higher education was restricted by numerous formal and informal practices, so as to 'protect' this area from massification. Despite the official willingness to grant equal access to higher education to different social groups, as well as official benefits for representatives of industrial and agricultural workers during the admission process, and the organization of a special system of preparatory courses, children whose parents owned a higher education degree had better chances to access the higher education system. Access to higher education could be an excellent illustration of the doublestandard policy in Soviet Ukraine, which indicated that there was a huge gap between official rhetoric and real practices of university admission. Unfortunately, this gap, together with unofficial practices which tried to break the constraints of the admission process paved the way for the corruption that would flourish in Ukraine's independent higher education system during the 1990s. 


\section{References}

Bunina, L.M. (2013) 'Istoriya vischoi osviti v Ykraini'. http://nbuv.gov.ua/j-pdf/ nvd 2013 3 2.pdf

Coleman J. (ed.) (1965) Education and political development. Princeton:

Princetopn University Press.

Dzuba, O.M., V.S. Shan. (2003) 'Visha osvita v Ykraini'. Entsiklopedia istorii

Ykraini Online. http://www.history.org.ua/?termin=Vyscha_osvita

Jacoby S. (1971) 'Toward an Educated Elite: The Soviet Universities'. Change 3(7):33-39.

Kremen, V. and S. Nikolajenko (2006) Higher Education in Ukraine. Bucharest: UNESCO-CEPES.

Ledeneva, A. (2014) 'Economies of Favors or Corrupt Societies? Exploring the Boundaries between Informality and Corruption'. Baltic World 7(1):13-21. Masal's'kyy, V. and H. Dymydenko (2010) 'Klasichni yniversiteti Ykraini: istoriya pohodzhennya ta zmist terminy', http://dspace.nbuv.gov.ua/bitstream/ handle/123456789/22417/23-Masal\%27s\%27kyy.pdf?sequence $=1$ Myronchuk, V.D. and G.S. Igoshkin (2002) Istoriya Ykraini. Kyiv: MAUP. Neave, G. (2011) 'The Expansion of the Soviet University Model' In Rüegg, W. (ed.) A History of University in Europe. Volume IV. Universities Since 1945, pp. 35-40. Cambridge, UK: Cambridge University Press.

Oksamytna, S. (2011) Mizhgeneratsiyna ta osvitnya mobil'nist'. Kyiv: NaUKMA.

Oksamytna, S. (2006) 'Sotsial'no-klassovie osnovi obrazovatel'nogo neravenstva v Ykraine'. Sotsiologiya: teoriya, metodi, marketing, 3:116-136.

Onischuk, O.A. (2013) 'Systema pidgotovki kadriv naykovo-tekhnichnoi inteligentsii cherez merezhy vischih navchal'nih zakladiv YRSR y drygiy polovini 1950-h - pershiy polovini 1960-h rokiv'. Naukovi pratsi istorichnogo fakyl'tety Zaporiz 'skogo natsional'nogo yniversitety, 36:180-186.

Osipian, A. (2008) 'Transforming University Governance in Ukraine: Collegiums, Bureaucracies, and Political Institutions', http://mpra.ub.uni-muenchen.de/11058/ Prokofiev, M.A., Chilikin, M.G. and Tulpanov, S.I. (1961) Higher Education in the USSR. Paris: UNESCO.

Savelyev A.Y., Zuyev, V.M. and Galagan, A.I. (1990) Higher Education in the USSR. Bucharest: UNESCO-CEPES.

Serhiychuk, O.M. (2002) Visha Shkola Ykraini v ymovah liberalizatsii syspil'nogo zhittya 1953-1964. Avtoreferat disertatsii na zdobyttya naykovogo stypenya kandidata istorichnih nayk. MS.

Titma, M., Brandon N. and Roosma K. (2003) 'Education as a Factor in Intergenerational Mobility in Soviet Society'. European Sociological Review, 19(3):281-297.

Young, M. (1994) The Rise of the Meritocracy. Piscataway, NJ: Transaction Publisher. 